\title{
FROM MUSHALLA TO MOSQUE: The Formation of South and Southeast Asian Muslim Communities in Japan ${ }^{1}$
}

\author{
Ali Amin \\ IAIN Manado \\ Email: aleejtr77@gmail.com
}

\begin{abstract}
Since the 1980s, Japan has attracted Muslim immigrants, mainly from South and Southeast Asian countries. The emergence of these Islamic communities in Japan is reflected by the presence of around one hundred mosques and musallas (rooms or buildings for the performance of five daily prayers) on the Japanese archipelagos. This paper aims to discuss South and Southeast Asian Muslim communities in Japan, and the spaces used for their rituals and social activities as they have developed into full congregations able to support mosque construction and maintenance. I investigate how the transnational aspect of migration has shaped the architectural availability of places of prayer, and the development of the ummah (Muslim community). My data was collected from observation of Indonesian and Indian mosques in the greater Tokyo region between 2015 and 2017, and interviews with their congregations.
\end{abstract}

Keywords: Mushalla; Mosque; Formation; Muslim; Community; Japan.

\section{INTRODUCTION}

This paper about the presence of mushalla (prayer room) and mosques as Islamic spaces addresses the development of immigrants' architectural building and the formation of Muslim community in Japan. In Japan, as such spaces are mostly built by transnational immigrant communities from South and Southeast Asia. This paper aims to discuss specifically the architectural and institutional transformation of mushalla and mosque within the transnationalism framework. The main question is whether the context of "foreign spaces" in Japanese host society is represented in the architectural

${ }^{1}$ This paper was originally prepared for the 2016 Universities Art Association of Canada conference in Montreal for a panel 'Beyond the Mosque: Diverse Sites of Muslim Prayer.' It was presented with a title "The Mushallas of Tokyo: The Architectural Development of Islam in Japan. I would like to express my gratitude to the panel chair Dr. Angela Andersen (Univ. of Victoria, CA) who had sacrificed her time to read and provided precious feedbacks for the panel version. Although this updated paper has different direction from the original version, some parts of the paper come from our discussion. 
building and community development.

Islamic space refers to a physical and nonphysical territory on which Muslims perform activities related to their religious beliefs and custom. It includes institutions, architectural buildings or sites, interiors and exteriors that mark Muslim's presence or visibility (Metcalf, 1996). In Muslim countries, various public facilities are set to accommodate Muslims' obligation to perform daily prayers. The architectural layout of most public facilities such as schools, shopping centers, tourism spots, train stations, airports but even military bases always provide a space for Muslim' prayers. The Jakarta International Airport in Indonesia for example, provides not only mosques outside and inside the terminal building but also mushalla (prayer rooms) in almost all domestic departure gates. Those facilities are created on purpose to help Muslim visitors remain cognizant to their Islamic obligation of prayers.

Additionally, in most Muslim countries, like Indonesia and Malaysia for instance, not only private but also public property and institutions provide and maintain their Islamic nuance. Almost everyday at certain times, there is a call for prayers (Arabic Adzan) from those prayer rooms which is amplified by outdoor loudspeakers. It signs a time for prayer, when Muslim is expected to pause his "secular" activities. In Saudi Arabia and other Muslim regions, when adzan starts, people stop doing any commercial transaction and close their shops, offices, markets. In a brief, living as a Muslim in majority Muslim countries, one would feel socially facilitated to perform their religious activities because public spaces have been Islamically modified (Hakim, 2013). In some countries such as Saudi Arabia, Pakistan, and Iran, even individual choice for being less or "slow" Muslim might be more threatened as local social force is very demanding (Algar, 2015). This work attempts to discuss the life of Muslims in the current era of global migration, where millions of Muslim immigrants earn their lives in non-Muslim majority countries. It is interesting to explore how they perform and maintain their Islamic faith and practices in the lack of such social force and spaces by taking into discussion of mushalla and Mosques and the migrant Muslims from South and Southeast Asian countries living in Japan.

\section{THE DEFINITION OF MUSHALLA AND MOSQUE}

The Arabic term mushalla means a place for prayer. The commonly literal meaning of the word, is no different from "masjid" (from the Arabic root Sa-ja-da), "mosque," which is translated as "a place" for worship (Syafe'i, Makhmud, 2016). Sujud, which is also from the "sa- ja-da" root, means to put one's forehead on the ground, as in the position taken during prayers. 
According to the recorded sayings and deeds of the Prophet Muhammad, known as hadith, as reported by Imam Ahmad, the masjid denotes the broader concept of Muslim prayer. The Prophet said, "In the whole earth, wherever you stand is masjid" (Fanani, Achmad. 2009). In everyday practice, however, a masjid, also called a djami in many languages, refers to a specific building intended as a center of communal Muslim activities including congregational Friday prayers, sermons, and Islamic tutorials. In contrast, therefore, similar structures, buildings, or spaces intended for the use of smaller community or individuals can be defined as mushalla.

In rural areas in Indonesia and other Southeast Asian countries, the distinction between mushalla and masjid is very clear, and is rooted in the understanding that mosque is the center of the Muslim community (Khan, Hasan-Uddin 1990). Based on the strong notion in traditional Indonesian society, one cannot establish a new mosque as long as the old mosque remains convenient for the whole village. In that frame of thought, the mushalla is a smaller spatial order used at the periodic convenience of segments of the Muslim community, which does not wish to separate itself ideologically from its larger mosque unit and the territorial unit (such as village) as a whole. In urban areas, for the sake of time and convenience, prayer spaces exist in almost every workplace, in shopping centers, and in hospitals, bus stations, schools, government offices, universities, army or naval bases, sport centers, and even prostitution areas. This marks a late twentieth-century transformation in the concept of community, from a group of individuals where they live, to individuals of where they work (Urry, John 2012).

A mushalla may in fact develop into a mosque because of a need for a larger place of worship in its particular location, along with the establishment of a sufficient number of members and funding resources. This is often the case amongst Muslim groups living within predominantly non-Muslim communities, and, as I will discuss, the effect of transnational forces upon architecture. In this paper, I will explain first the establishment of musallas in Japan by Muslim migrants and their associated national governments and business interests, and community groups showing how early Muslim neighborhoods or groups and their distinctive prayer spaces are formed in the context of Japanese society. Secondly I will discuss the process of establishment of mosque showing the formation of larger Muslim community than that of mushalla congregation. I will contextualize the background of Muslims as a minority in Japan, and present several architectural examples of mushalla as the result of my fieldwork with South and Southeast Asian communities in the greater Tokyo area. 


\section{ISLAM AS MINORITY IN JAPAN}

Although Islam is considered to be a growing religion in Japan, the Muslim community numbers between seventy and one hundred thousand people, based on estimates from the past ten years (Kojima, Sakurai 2012, 2008). Making up less than one percent of Japan's total population, most are immigrants from Indonesia, China, and South Asia. The largest influx of Muslim immigrants arrived in Japan during the booming industrial period of the 1980s. As Japan recovered from the global oil crisis and reached its peak industrialization level, corporations needed more workers to maintain their productivity so the Japanese government took the rare step of permitting the entrance of foreign nationals including migrants from Muslim countries such as Pakistan, Iran, Bangladesh, India, Indonesia, Malaysia, and Middle Eastern countries (Kojima 2006).These and more recently arrived workers continue to face discriminatory attitudes from the Japanese people, who remain unaccustomed to their cultural and religious practices, and the differences in their physical appearance and customs. This has created challenges to Muslims who hope to find better jobs, and to locate housing, education, and marriage partners. The result is insular community formation, often undertaken in isolation from the Japanese surroundings.

These South and Southeast Asian Muslims are vulnerable to social marginalization, linguistic and cultural barriers, and other problems caused by the recent global stereotyping of Muslims as potentially dangerous and suspect. The burden for being Muslim migrants is more severe than other foreigners in Japan (see Sakurai 2008). Individual Muslims have to overcome not only the language and cultural barriers, but also the facts that Islam is too foreign to Japanese literature and consciousness (Onishi, Akiko, and Stephen Murphy-Shigematsu. 2003). Most knowledge and perception about Islam are relied on the Western media information, hardly from direct interaction between individuals. A survey among high school students in Japan, for example, reveals that what Japanese students recognize most about Islam and Muslim are related to negative stereotypes such as strange custom, terrorism, sectarian conflicts, gender inequality, and anti-democracy (Maruyama, 2007).

\section{MOSQUES AND MUSHALLAS IN JAPAN}

There are around 80 mosques and mushallas in Japan, existing throughout the Japanese archipelago from Hokkaido to Okinawa. The Kanto area, consisting of Tokyo, Chiba, Kanagawa, Ibaraki and Gunma, has the greatest concentration. Most mushallas are established by donations from the foreign Muslim communities living in Japan. A few mosques in central Tokyo were 
built under the auspices of the Turkish and Saudi governments, and I will discuss a mushalla/mosque associated with the government of Indonesia below. Many Muslim organizations and local associations in Japan, such as the Islamic Thrust of Japan, Islamic Circle of Japan, Japan Muslims Association, Chiba Islamic Community and the Muslim Associations of Sendai, Tsukuba, Hamamatsu, Fukuoka, Nagoya and Osaka also take a central role in establishing prayer spaces.

Mushallas in Japan are operated by several owner categories, such as private companies and individuals that might also receive donations from others. They may also belong to groups who agree to establish the mushalla and share the expenses, or they may belong to a Muslim community or ethnic organization. There are also several Japanese mushallas belonging exclusively to business enterprises or offices, stores, Muslim restaurants, campuses, airports and train stations, as well as those belong to embassies of Muslim countries and state enterprises such as Indonesian oil company Pertamina and Petronas of Malaysia. The following descriptions of Indo-Pakistani mushallas in the Nishi Kasai and Shin-Okubo, Indonesian mosques in Meguro, and Tochigi districts have provided insights into how they were established and developed, how they are (or are not) adjusted into the surrounding cultural and architectural fabrics and social fields.

\section{NISHI KASAI MUSHALLA}

Nishi Kasai Mushalla represents the typical formation of early Muslim immigrant community in Japan which is not unusual among Indonesian community either. ${ }^{2}$ Several co-ethnic or co-national Muslims settle in the same area and share the same needs for a mosque where they can perform prayers and other religious activities. First they agree to pray together in someone's house, then they agree to pray from one place to another circling the member's' residences. When the membership gets bigger and face some challenges to accommodate their activities, they start renting a place allowing them think the next steps, building mosque. This step is what exactly I saw from Nishi Kasai mushalla community formation which now plans to have their own mosque in the near future. Most of the following narratives refer to two interviews with the board members of the mushalla and field observation I conducted in summer 2016.

Nishi Kasai neighborhoods called Tokyo's little India has at least 15 families (around 60 people including kids) out of 300 Indian settlers are Muslim. After recognizing each other through the mosque they attended away from the

\footnotetext{
${ }^{2}$ More information on the mosque please visit http://eibc.jp/
} 
neighborhood or from online social media, several individuals agreed to pray once a week at someone's house. They then agreed to pray together weekly at an apartment of the group members on circular basis. When membership number increased they rented sport hall every weekends and Ramadan (Fasting) month. During Ramadan month in 2012-2014 they used to utilize a room at a community hall for night prayer. Unfortunately since 2015 , the sport hall management has changed its regulation: they closed the building facilities earlier prior to the time of night prayer. In 2015 members of the group agreed to rent a room prayer.

In the beginning, process of the building search is quite difficult because of two reasons. First with the limited budget they requested, a location nearby Nishi Kasai station is a rarely available. Secondly the building owners hardly agree with a proposal of religious activities, especially foreigners. There is no way to rent a building under Mushalla or mosque contract. After several months of searching, with the help of local Islamic organization (ITJ, Islamic Trust of Japan), they finally decide to rent a vacant office around four minutes of walk from the station, priced 80-90 thousands a month. Just like many other nonpermanent (some are permanent) mushalla building in Japan which are not officially registered as mushalla or mosque for their property status, the legal name of organization is Edogawa Islam Bunka Center under which its registered main activities is cultural and religious services. In addition to daily prayers, the mushalla now run several programs for its members as well as general public. Besides five time prayers, they also run Quran and Arabic classes for children every weekends and one Islamic class for public on different day. All the family members also have a bi-weekly and monthly program whose aims to get all the members stay closer to each other. Additionally, the Mushalla congregation regularly joins voluntarily works with local community.

The room for the mushalla is located on the second floor of five floor building. It is basically a studio office which has no separate panel and minimalist facilities. The only facilities available inside the room are a kitchen set, toilet and bath room. It can be occupied by maximum of 20 people in one time. This is because a few spaces are not used effectively. This is also due to the context of Japanese architectural design which is structured originally not for the purposes of Mushalla. In Muslim countries, Mushalla building must head toward the Mecca (qibla, in Japan West direction) and set the entrance at the end back of the building (east direction) while this room has the entrance at the head of the room making it impossible for imam to stand at the middle of the room. Also this prayer room has a bathroom and toilet area at the entrance side which is on the West side and connected to the kitchen set along the right 
side of the room. This makes one side of the room unfavorite place for the visitors. People would not prefer praying at the closest area to the toilet and kitchen which is in the same room. On the other hands during prayer, people would pray always behind the imam, therefore the empty space and the rest room area in front of imam would not function. Having limited space, the mushalla however, have no a specially separated place for female congregation. During the peak session like the evening and night time, female worshiper is hardly seen at the mosque. They do activities mostly on the days during the weekends.

\section{SHIN-OKUBO MUSHALLA}

Located in a busy district, the Shin-Okubo Mushalla reflects the growth of culturally heterogeneous neighborhoods in Japan. The Indian, Pakistani, and Bangladeshi migrant congregations strengthen the impression of plural society of the "Koreatown" district dominated by the families of Korean workers, and numerous businesses, fast food shops, entertainment, hotels, restaurants, Korean merchandise shops, and Indian, Bangladeshi, Indonesian and Nepalese restaurants and grocery stores, all of which use their language characters on their shop board name. There are several old Shinto and Buddhist shrines, and large Korean and Catholic churches nearby. The Shin-Okubo mushalla is located adjacent to the Shin-Okubo train station of Yamanote line, the main train track in Tokyo connecting all popular industrial and entertainment centers in the city.

Unlike the Shinto and Buddhist shrines or the church in Shin-Okubo, which are visible from the main street, the Mushalla is "hidden," presenting no markers until visitors arrive at the first floor of the building, where a small sign instructs them that there is a "Mushalla on the 4th floor". Even if one stands outside facing the building, the Mushalla is hardly recognized until someone with a South Asian or Arab background might be asked for directions. A senior member of the mushalla explained to me that the establishment and development of the site has come together with the success and growth of the corporate owners, Green Nasco Company in Shin-Okubo, although operator Mr. Yusuf (alias name) did not wish to elaborate upon why he rented the building in that area almost 20 years ago. The mushalla was originally established by a Nepalese Muslim shop owner and taken over by Nasco, which has also purchased the adjacent building. Collectively, the buildings are used for the mushalla, a grocery, halal meat supply, and as family housing and a warehouse.

The mushalla space on the fourth floor is approximately 80 square meters, 
including three rooms that were formerly used for business or as a studio apartment and toilet facilities for men and women. These are connected by the stairwell and corridor where visitors remove their footwear. Women have access to one of the rooms, except during the Friday prayer when it is used for the imam and preacher. Each room has water taps that are utilized for the ablution ritual prior to prayer, normally performed in a separate facility. These are separated from the prayer space by portable dividers that can be stored during the more crowded Friday prayers. Unfortunately since men ablution area is on the west side of the room, it creates inconvenience look during Friday prayers. As people are ready for prayer, several others remain queuing up for ablution ritual in front of the praying congregation. Secondly, as the smaller room unit for woman is isolated in the most westward area. Woman congregation cannot follow the man group during their everyday prayers; as such organization makes men behind the women a state which is unlawful according to an Islamic jurisprudence. Most of South Asian mushalla or mosques I visited in Japan has no room or have only smaller room for women. The women room is located at separated floor or room, prohibited for men.

The Shin-Okubo mushalla represents a specific kind of South Asian Tablighi "subculture". It places a particular emphasis upon communal prayer and activities. A long, Pakistani style jubah or robe, a distinctive, popular perfume, and the use of Urdu as the "official" language of the mushalla for all written and spoken information, printed calendar, the Friday sermon and the Thursday night lecture are markers of the space and its community. The Mushalla itself sometimes functions as the "transit shelter" of Tablighi travelers, who might stay between one and several nights on futons at a secondary prayer room as they conduct Islamic propagation in Japan. Unlike Tablighi mosques in South and Southeast Asia, which allow cooking and laundry activities, the travellers in Shin-Okubo must buy outside food, and eat together inside the mosque.

Compared to other mosques in Tokyo, the physical appearance of the mosque is underdeveloped. The building looks old as shown from its tainted walls, carpets, curtains and ceilings, as well as old fashioned toilet except one for the women section which is under the standard of Japanese public hygiene lifestyle. The mosque's interiors look below the standard. Yet it is very active mosque and overcrowded Friday prayer congregation for its location on one of the busiest district in Tokyo and have easy access from the main train tracks circling Tokyo. Additionally its compromise to the workers lunch hours, on Friday, the mosque sets the afternoon prayer one hour behind the normal time prayer, making "people able to come here after they had lunch" (at 01.00 pm)," a senior member says. The later Friday prayer schedule is also to give 
different choices of prayer location on Friday. Those who prefer earlier time might go to Otsuka mosque, or other mosques that start the Friday prayers at 12PM.

\section{INDONESIAN MUSHALLA}

Located inside the Indonesian embassy property, the Indonesian School in Tokyo's legal status represents the unique relationship between religion and state in Indonesia, which recognizes all existing religions as foundational sources of the state, and an aspect of Indonesian cultural identity. Therefore, much religious architecture such as mushallas, churches, and temples are constructed on state property. Although there is no operational relationship between the Indonesian School mushalla communities and the embassy, two unwritten customs determine how the association of the Indonesian Muslim Community in Japan, known as Indonesian Muslim Community Association (or KMII), is partially dependent on the embassy and vice versa. The Mushalla which is now already becoming a mosque sits on a property belong to the embassy, but it is KMII which has a right to claim at as a head quarter of its organization. In addition, the leadership of KMII must include an embassy staff member so the embassy considers this as a part of their social advocacy and citizen monitoring programs.

The Indonesian School mosque is unlike other public mosques in Japan as it is a property of Indonesian government, and the congregation is primarily comprised of embassy and school staffs and their friends, family, and business and supporting partners. The practical work of maintaining and cleaning the mosque and running events is undertaken by this congregation. During school hours, the mushalla, is a prayer place for the Indonesian School students, although others are welcome. Located in the corner of the school building with accompanying ablutions facilities, it is entered by the wider community primarily during morning and evening prayers, after which the imam recites and explains Quranic verses. On Sunday morning, lectures are conducted in the mushalla area, where people also can enjoy Indonesian breakfast. The mushalla space is too limited to accommodate Friday prayers, which consequently move to the school auditorium on the second floor, made into the prayer place by covering the floor with carpet and setting up a stage for the imam.

\section{SRIT MUSHALLA AS TRANSNATIONAL MUSHALLA}

Transnationalism which is a popular perspective in social science is the idea that human relations and social fields are spanning nation borders. It 
is according to Schiller (1992: 1) and Levitt (2001) "the process by which immigrants build social fields that link together their country of origin and their place of settlement." In other words, it relates to a new phenomenon of migration which does not only engage activities in the new society, but also in their sending countries and beyond (Levitt, 2001). In that frame, I consider that the SRIT mushalla is a transnational space and organization which advocate two cultures at the same time: the hosting culture: Japan, and the origin or the sending culture Indonesia.

The SRIT mushalla congregation lives in Japan earning life, working with Japanese companies, and environment where they are exposed to the Japanese culture. On the other hand, their thoughts, their communication, their friends and contacts, their foods, even their dress and some of their custom remain Indonesian. The SRIT mushalla is one of the agents that maintain the national identity of Indonesian Muslim in Japan. Once one steps the SRIT ground, she or he will seemingly no longer feel he/she is in Japan. They will no longer feel the stress of being immigrants and Muslim in Japan with their problem of language, or food and of course minority status. KMII with its JMS has become the main organization that provides this Indonesian atmosphere to its congregation. Individually, facilitated with the advanced of communication technology, Indonesians just like other current immigrants can easily communicate with their contacts in their origin places in Indonesia. Yet they feel remain lonely without being affiliated to ethnically Indonesian groups. In terms of their religious group membership, KMII might provide a needed solution for this kind of being in a group as well as make them remain connected to their home culture. Some of Indonesian and Japanese customs are used representing the transnational culture of the Indonesian immigrants, as similar kind of customs which also popular in another Indonesian mosque; Sano mosque in Tochigi.

\section{SANO MUSHALLA}

Sano Mushalla (now called mosque) in Tochigi, about two hours from Tokyo, is another mushalla of Indonesian Community in Japan. Unlike SRIT Mushalla whom most congregation are students, professional and their family members, the Sano Mushalla congregation members are a representative mosque from the working class; mostly Indonesian trainees (kenshusei) whose maximum formal education is senior high school. As commonly known, training program in Japan are often partially considered as a camouflage program to invite cheap workers from outside Japan. Trainees who supposedly learn 
to increase their work skills and upgrade their experiences are "trapped" in the kinds of extremely hard works. A very little work experience that they can learn and bring back to their country with the condition that most of the works in Japan has been automatized. Most of the trainees I met feel exploited by the heavy and demanding works. On the weekdays they do not have time to enjoy interaction with others. They depart around 7 am from their shelters and arrive from the work between 6 and $8 \mathrm{pm}$. The salary they got however far less than the Japanese workers while their work responsibilities are equal to or even harder than that of their Japanese fellows. In that sense, Sano mosque becomes a very vital place for kenshusei to share their distress and feeling of solidarity and togetherness. Many expressed that the existence of Sano mushalla for them is like an oasis in the desert providing spiritual and religious understanding.

The whole old Sano musholla before relocation was structurally an old wooden warehouse. Before the Sano Muslims used it for mushalla, a Bangladeshi immigrant rented it for halal meat shop therefore a shop billboard until currently remains there. The congregation members have chosen it for a mushalla after exhausting time searching for possible building for their religious activities. The house has around 150 meters square consisting of the two floors with some facilities including big hall (used for prayers), two toilet rooms, bathroom, kitchen, guest room, and living room. All those facilities excluding the hall and one toilet are on the second floor. Although they remain functional, most of the facilities look out of mode, and need repairing. The mushalla congregation also established a temporary ablution area in the side of the building by installing several water taps. The mushalla rented the building for 40 thousand yen a month which is collected from the member's donation.

Since the founders and most of its congregation are Indonesian Tabligh members, the two dominant cultural expressions in the mosque are Indonesian culture and Tablighi customs. They communicate and talk in Indonesian language or their regional native languages. They also eat Indonesian foods, as well as practice Indonesian culture. Their Tablighi transnational subculture appears in their everyday appearance, habit and customs including wearing South Asian robes when praying, preaching specific hadis after every prayer, visiting a friend missing the everyday prayer, a group dinner one plate for at least three people commonly practiced by Tablighi members in South Asia. The mushalla also has become a Tablighi shelter for the travellers from around the world when they visit Japan. The mushalla congregations including the "on duty" kenshusei have to do two hours missionary agenda everyday: to 
talk and visit people inviting them to mosque. In the evening, they check if there are Indonesians around them who do not come to the mosque. In the weekends, they can visit any Indonesians living in Sano as far as 15 minutes driving away from the mushalla. They pick up them by car and return them back after isya prayer. Yet with the arrival of imam ustaz Hashim who has strong root in Nahdlatul Ulama tradition, the religious discourse circulating among the mushalla members is culturally NU discourse influence.

In Indonesia, like in other Muslim worlds, Islamic discourse has been spoiled by the interpretation of transnational neo-Islamism of Wahhabism which upsurges the idea of Islamic purification from non-Islamic culture. This in return has challenged the existing tradition of Islam which is very friendly with the local tradition where Islam exists. In India, Africa, and south Asia, Islam has been friended with the local culture which are relatively very tolerant to the other coexisting cultures. The new interpretation of Wahhabism with its purification idea has marginalized the old tradition as well as incites opposition from them in many Muslim worlds. As many of those who come to Japan are influenced by this idea from their home countries, or during their interaction with other Muslim fellows in Japan, ustadz Hashim, the Sano Imam has responded emphasizing on traditionalist Islam representing the current discourse circulating in Indonesia. The purified group insists on the free interpretation of Islam based only on Quran and Hadis. The traditionalists provide additional resources to more understand Quran and hadis through the interpretation of ulama (Muslim scholars). Ulama are the trusted resources to understand the words of God and the words of prophet. We only follow what the ulama have said, ustadz Hashim says. In many cases, I saw the traditionalist nuance of Islamic teachings being taught in Sano is countering the modernists notion of Islam which is dominant in KMII mushalla. Many Islamic discourses such as performing rituals of "slametan" (prayers for the dead), which is prohibited according to modernists, is allowed according to Sano mushalla. This is an interesting topic to elaborate. For more discussion on this issue will be provided in a forthcoming paper.

\section{ARCHITECTURAL TRANSFORMATION}

Before entering the mosque or musalla to perform prayers or to recite the holy Quran, Muslims must do a purification ritual (wudhu) which contains ritual of washing face, hands, and feet. In Muslim countries the wudhu location or midoah (Arabic) is commonly separated from the prayer area. As wet area, in the rural areas of Indonesia even the midoah is often placed on the different building or floor where people walk a few meters steps to the main prayer 
room. The contemporary common design of midoah in Indonesia is just like typically public restroom with some water taps attached to wall. Some old mosques remain preserving traditional model of structure, where people do the $w u d h u$ from the big bath pool. Some midoah are made in mixed style between the old and the modern one where people do the wudhu from the water taps, but do sink their feet in the small and shallow pool upon entering the prayer area. Midoah of Japanese mosques is also usually built on the back area of the prayer hall although some transformations are made on the midoah structure, design and appearance due to some budget and cultural adjustments.

The midoah building is usually structured and designed according to the midoah of Muslim home country. They function the building as a wet area similar to ordinary bathrooms in Japan. This is exactly what I saw in Camii mosques, Saudi Arabia mosques, Indonesian mosques, and almost all mosques affiliated to ICOJ. On the contrary, some rented building functioning for mosques remain in the Japanese style, dry area where one can wash their hands on the hand wash basin and put one's feet on it. The Shin-Okubo mosque is an example of this type.

Likewise, due to their custom of doing ablution/purification before every prayer (five times a day), most Muslims, especially those from tropical countries prefer wet toilets than the dry one. In Indonesia, for example, most of the luxurious supermarkets and hotels have small mosque where Muslims perform their daily prayers. Likewise in Indonesia wherever we go, be it at to either gas station or five star hotels, we will find additional facilities for Muslim purification rituals. Muslim do ablution rituals before five daily prayers, and most of them (Indonesians) do not use tissue papers for cleaning their body. Surprisingly the Japanese technology with a new faucet toilet machine is very friendly to the Muslim customs. Every Muslim seems preferring water to paper tissue for their "cleaning activities". In Muslim countries, it is common to hear azan, call for prayer lauded through the public air five times a day. While in Tokyo or New York we hear ambulance or firefighter serine almost every hour, in Muslim cities like Jakarta or Cairo we will hear call for prayers from loudspeakers.

\section{COMMUNITY TRANSFORMATION}

Since 2017, the two mentioned Indonesian mushalla have transformed into a mosque. The SRIT mushalla once a small room inside the school building, now is a permanent and independent building taking a place on another part of the SRIT ground. Named Masjid Indonesia Tokyo or MIT, the mosque 
was launched in Ramadhan 2018. It is used for daily and weekly (Friday) prayers. Previously, in 2017, after clearing their building purchase, Sano mosque was also launched. Having their own building complex, once was a abandoned warehouse, the kenshusei congregation in Sano gradually left their old rented mushalla and officially moved into a new and much larger space for their communal activities. The establishment of two mosques owned by Indonesian community marked a new phase of Indonesian Muslim's roles within International Muslim communities in Japan.

South Asian immigrants have played important roles among Muslim immigrant communities in Japan. They have grown up since the 1970s and played an important role in the Muslim community leadership of the country. Most of the foreign Muslim's religious activities were managed by the South Asian origins especially Pakistani. They occupied not only mosques affairs, but also some other "Islamic" fields such as halal grocery, Hajj and Umrah (traveling) to the holy lands, Islamic school or madrasa, and the dead burials. Lately the increasing entrance of Indonesian students, trainees, nurses, workers and tourists has enacted alternative players from within Indonesian Muslim immigrants. Many Indonesian permanent residents also run their own enterprises such as halal shops, restaurants, online grocery, tour and travel and money remittance. With the growing number of Indonesian Muslim community, while South Asians remain dominant in halal business, and grocery, they aware Indonesians are the largest market of their "Islamic" products. Therefore currently Indonesian imported products such as seasonings, noodles, meat balls, tempeh, soy beans, and other sources are always available at South Asian stores.

The influential role of the South Asian immigrants among the international Muslim communities is recognized because majority of them are permanent residents (or Japan citizens). Unlike Indonesian immigrants who do rarely intend to live permanently in Japan (as a Japanese citizen), large number of young and middle aged South Asian are Japanese citizens or permanent residents. Many of Pakistani and Bangladeshi men are married to Japanese, having children and get Japanese passport (Kudo, 2009). After long time life in Japan, they imagine Japan as their homeland and will live there for the rest of their life. This shared situation among Pakistani/Bangladeshi-Japanese spouses for example produce strong will among them to establish mosques, not only a place for prayer but also a community center. They envision new place which present them cultural environment they used to live with in their origin countries. Establishing a mosque is an important step to fulfill their desire to live in this world's most advanced country and remain with their 
cultural origins.

Since the 1990s, while the number of South Asian immigrants stag, the number of Indonesian immigrants increases (Kojima, 2006) due to a new policy allowing unskilled and "semi" skilled employment. The policy creates opportunity for young Indonesians to work in Japan under various programs namely training (internship) and "health care. Those programs along with growing interest of studying in Japan make the number of Indonesian immigrants in Japan grows. Soon they need more spaces for not only religious rituals but also socialization. The presence of mosques allows more number of congregation or participants to attend or participate in rituals and events organization. Indonesians living nearby the mosques no longer go to the South Asian mosques rather some International Muslim communities do their prayers at Indonesian mosques, instead. Consequently this situation, as I found among my foreign informants, makes a positive impression on Indonesia and its citizen.

One of the Rohingya informants for example says "Indonesians are good Muslims" They have a good and strong unity. They regularly make religious meeting not only at Indonesian mosques but also at our (South Asian) mosques. They are also very generous doing fundraising for our brothers and sisters in Rohingya as well as donation support for our mosques. Islam in Indonesia seems very powerful. They support greatly for Palestine! Recently, you know, Indonesians make the largest historical demonstration against Holy Book defamation by a governor (Ahok!). We are proud of Indonesia (Islam in Indonesia). Please do not stop supporting us brother!"

Ramadan 2018 proves to be the first time for Indonesian Muslim community to host "Ru'yat Hilal" meeting to observe the end of Ramadan participated by Muslim representatives from international communities in Kanto area. An Indonesian Muslim leader acted as the meeting chair, welcoming the guests, reporting about the mosque building process and activities and finally signing up the decision letter from the meeting members. Indeed the establishment of the mosque not only a religious mobilization for the Indonesian congregation in Tokyo but also providing equal role for Indonesians before the International Muslim communities in Japan. Indonesian Muslim Association signature has been long time drawn on the official letters of Muslim communities in Japan but only recently it sounds a pride identifying Masjid Indonesia Tokyo as their official address.

\section{CONCLUSION}

The existence of Muslim immigrants in Japan has contributed to the dynamics 
of Muslim diaspora discourse within the issue of modern Muslim world. For the case of Muslim diaspora in Japan, especially with the origins of South Asia and Southeast Asia discussed in this work, two important points I have drawn in. First is about the social functions of mushalla as giving the transnational spaces for its congregations. The mushallas of Shin-Okubo, SRIT (KMII) and Sano have provided their members a home culture such as language, dress, food, customs, music, hands crafts, and the existing social, political, and religious discourses in Indonesia. For their congregation, the presence of such environment at the mushallas has provided the spaces to get rid from the tense of their workplaces, and being minority group as well as being away from their home.

Secondly, studying mushalla's architectural development makes us understand the early formation of immigrant community in Japan which continuously will grow in the future. The growing number of mushalla and mosques provides evidence the growth of Muslim population as well as Muslim visitors. Most of the existing mosque buildings currently in Japan began as a mushalla and non-permanent prayer rooms established by individuals or small groups of Muslims. As the mushalla communities grew and were able to expand, they worked to establish a larger, permanent building or site for their mosque.

Lastly, besides Sano and MIT mosques, some mosques have been constructed by International Muslim community in Japan such as of that in Tsukuba, Chiba, Sendai, Kyoto, Shinjuku and and Shibuya. It is interesting that Indonesian community appears recently to be very strong supporters in those projects. They do not only do a fundraising from among the Indonesian immigrants in Japan but also from the public Indonesia. Providing a discussion on mushalla, study on the similar theme and the growing Mosques and their communities including the Indonesian ones could be one of many ways to understand Muslim immigrant groups in Japan.

\section{BIBLIOGRAPHY}

Algar, H. (2015). Constitution of the Islamic Republic of Iran. BookBaby.

Douglass, M., \& Roberts, G. (2015). Japan and global migration: Foreign workers and the advent of a multicultural society. Routledge.

Fanani, A. (2009). Arsitektur masjid. Bentang Pustaka.

Glick Schiller, N., \& Caglar, A. (2010). Locating migration: Rescaling cities and migrants. Cornell University Press.

Hakim, B. S. (2013). Arabic Islamic Cities Rev: Building and Planning Princi- 
ples. Routledge.

Khan, H. U. (1990). The architecture of the mosque, an overview and design directions. Expressions of islam in buildings, 109-127.

Kojima, H. (2006). Variations in Demographic Characteristics of Foreign Muslim Population in Japan: A Preliminary Estimation. The Japanese Journal of Population, 4(1), 115-130.

Kojima, H. (2012). Correlates of Cross-Border Marriages among Muslim Migrants in Tokyo Metropolitan Area: A Comparison with Seoul Metropolitan Area. Waseda Studies in Social Sciences, 13(1), 1-17.

Kudo, M. (2009). Pakistani husbands, Japanese wives: A new presence in Tokyo and beyond. Asian Anthropology, 8(1), 109-123.

Liu-Farrer, G. (2011). Religion and Migration in Northeast Asia1. Journal of Asia-Pacific Studies (Waseda University) No, (16), 59-75.

Maruyama, H. (2007). Diversity as Advantage in a "Homogeneous" Society: The Educational Environment for Muslims in Japan. Shingetsu Electronic Journal of Japanese-Islamic Relations, 1(March).

Metcalf, B. D. (Ed.). (1996). Making Muslim Space in North America and Europe (Vol. 22). Univ of California Press

Onishi, A., \& Murphy-Shigematsu, S. (2003). Identity narratives of Muslim foreign workers in Japan. Journal of Community \& Applied Social Psychology, 13(3), 224-23

Sakurai, K. (2008). Muslims in contemporary Japan. Asia policy, (5), 69-88.

Syafe'i, M. (2016). "Masjid dalam perspektif sejarah dan hukum Islam." Online).(http://file.upi.edu/Direktori/FPIPS/M_K_D_U/195504281 988031MAKHMUD_SYAFE'I/MASJID_DALAM_PRESPEKTIF_ SEJA RAH_DAN_HUKUM_ISLAM_(10_HALAMAN).pdf) (2016

Urry, J. (2012). Sociology beyond societies: Mobilities for the twenty-first century. Routledge.2.

www.://eibc.jp/

www.kmii-jepang.net

http://www.islam.or.jp/en/

http://www.icoj.org/ 
